\title{
The Potential Herbs of Medicinal Forests from Central Kalimantan as a Inhibitor of Staphylococcus aureus
}

\author{
Rezqi Handayani*
}

\section{Rezqi Handayani*}

Faculty of Health Science, Universitas Muhammadiyah Palangkaraya, Central Borneo, INDONESIA.

\section{Correspondence}

\section{Rezqi Handayani}

Faculty of Health Science, Universitas Muhammadiyah Palangkaraya, Central Borneo, INDONESIA.

\section{E-mail: rezqi.handayani@gmail.com}

History

- Submission Date: 04-04-2019;

- Review completed: 19-04-2019;

- Accepted Date: 19-04-2019.

\section{DOI : 10.5530/pj.2019.11.117}

\section{Article Available online}

http://www.phcogj.com/v11/i4

\section{Copyright}

(C) 2019 Phcogj.Com. This is an open access article distributed under the terms of the Creative Commons Attribution 4.0 International license.

\begin{abstract}
Background: Central Kalimantan is one of the largest provinces in Indonesia with a wealth of medicinal herbaceous plant species. This province was the origin of various medicinal plants such as tabat barito, akar kuning, pasak bumi and some other medicinal plants that were useful for human health. Methods: This paper explain about inhibitory test extracts etanol of Hati Tanah (Angiotepris Sp) tubers and Sangkareho leaves (Callicarpa longifolia Lam.) in Staphylococcus aureus bacteria with concentration 1\%, 5\%, 10\%, and $15 \%$. Both plants has been utilized by the community as a traditional medicine to treat minor to moderate injuries such as postpartum. Results: The results for extract Hati Tanah was $15.63 \mathrm{~mm}, 16.97 \mathrm{~mm}$, $25.42 \mathrm{~mm}, 28.40 \mathrm{~mm}$ and the results for and Sangkareho leaves was $1 \mathrm{~mm}, 2.68 \mathrm{~mm}, 3.9$ $\mathrm{mm}, 6.2 \mathrm{~mm}$. Inhibitory test studies have also been performed on the N-Butanol fraction from ethanol extract Hati Tanah tubers of the soil at the same concentrations and bacteria. The inhibited zone results was $15.65 \mathrm{~mm}, 23.20 \mathrm{~mm}, 24.15 \mathrm{~mm}, 26.25 \mathrm{~mm}$. Conclusion: Medicinal forest plants origin of Central Kalimantan is Hati Tanah tubers and Sangkareho leaves has potential as a traditional medicine in inhibiting and killing Staphylococcus aureus bacteria. Key words: Medicinal forest, Traditional medicines, Inhibitory test, Staphylococcus aureus.
\end{abstract}

\section{INTRODUCTION}

These day at modern medicine use many synthetic drugs. Synthetic drugs whose ingredients derived from synthetic chemicals. The chemicals have a variety of properties that can be used in therapeutic treatment. But in addition to having good effectiveness, chemicals also have side effects that are not good for the functions of organs in the body. Therefore, many people who choose to use traditional medicine using materials derived from nature as treatment therapy. This is in line with government support that issued the program "Back To Nature" one of them by utilizing the existing plants around the community as a traditional medicine ingredients. The world's dependence on medicinal plants is high. More pharmaceutical companies in industrialized countries and developing their products using basic materials from nature. Approximately 25\% of the world's pharmaceuticals are developing medicinal products with botanicals from plants. This proves that medicinal plants are very important for modern medicine. Pharmaceutical companies in developed countries generally do not have sufficient source of raw materials. They conduct aggressive exploration into tropical forest countries with a high biodiversity wealth to extract and research medicinal plants that are valued as valuable for modern medicine and utilize local indigenous knowledge about their use. ${ }^{1}$

Central Kalimantan with a total area of 15,380,410 hectares, the areas also save a lot of biodiversity for germplasm of medicinal plants. ${ }^{2}$ It is estimated that thousands of types of medicinal plants have not been discovered and cultivated, encompassing several new species (nova species), new records, or new spots. ${ }^{3}$ This province is the origin of various medicinal plants such as Tabat Barito, Akar Kuning, Pasak Bumi and some other medicinal plants that are useful for human health. Among the medicinal forest from Central Kalimantan that used as traditional medicine are the Hati Tanah (Angiotepris Sp) and Sangkareho (Callicarpa longifolia Lam.) Plants. Both medicinal plants has been utilized by the community as a traditional medicine to treat minor moderate injuries such as postpartum. Empirically the Hati Tanah (Angiotepris Sp) tubers and Sangkareho leaf (Callicarpa longifolia Lam.) believed to treat minor injuries, postpartum injuries, malaria and diarrhea.

Several preliminary studies have been conducted on both plants, one of which was the identification of chemical compounds contained in both plant simplicia. From the results of ground breaking experiments The Hati Tanah tubers contains chemical compounds was Flavonoids, Tanin, Catechol, and Saponin. While the leaves of Sangkareho contains chemical compounds Alkaloids, Flavonoids and Steroids. Based on these results have been scientifically proven that the Hati Tanah tubers and Sangkareho leaf has a pharmacological activity or efficacious as a drug. Therefore, this research is done to see one of pharmacology activities owned by both plants. From the empirical data obtained both plants are believed the public can accelerate the healing of minor injuries to moderate. The wound is a damage to the anatomical structure of the skin that causes skin disorders. Injuries can be worsened if you have an infection caused by bacteria. One of the bacteria that causes infection of the wounded skin is the bacterium Staphylococcus aureus. Staphylococcus

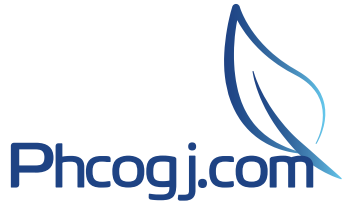

Cite this article: Handayani R. The Potential Herbs of Medicinal Forests from Central Kalimantan as a Inhibitor of Staphylococcus aureus. Pharmacog J. 2019;11(4):740-4. 
aureus can be found in the skin and in the human nose, (the nose is usually considered the main site of the development of colonization) and can sometimes cause severe infections and illness. ${ }^{4}$ Staphylococcus aureus is a round gram-positive bacteria composed like grapes. These bacteria are thought to be found in the upper respiratory tract, face, hands, and hair. Among the organs that are often attacked by Staphylococcus aureus bacteria is the skin that is injured. If the affected skin is attacked by Staphylococcus aureus bacterial infection it will prolong the healing process.

Therefore, this study was conducted to determine whether the two medicinal forest from Central Kalimantan has efficacy in inhibiting and killing the growth of bacteria, especially Staphylococcus aureus bacteria.

\section{MATERIALS AND METHODS}

The materials used in this research are simplicia, ethanol extracts, N-Butanol Fraction of Hati Tanah and simplicia, ethanol extracts Sangkareho Central Kalimantan and Staphylococcus aureus strain of ATCC 25923.

\section{Made simplicia}

Conducted a wet sorting on Hati Tanah tubers and Sangkareho leaves, then leaves and tubers are cut into pieces, and dried. After drying the simplicia it was re-sorted and mashed to a powder.

\section{Made extracts}

Extracts of Hati Tanah tubers made using by sokhletasi method, while the made of Sangkareho leaf extracts made by percolation method. Weighing the viscous extract obtained. The extracts were then made in various concentrations i.e., $1 \%, 5 \%, 10 \%$, and $15 \%$.

\section{Made N-butanol fraction}

N-Butanol fractions made from ethanol extracts Hati Tanah tubers.

\section{Made positive controls}

Tetracycline used as a positive control, made in various concentrations of $1 \%, 5 \%, 10 \%$, and $15 \%$.

\section{Inhibitory test}

Inhibitory test of ethanol extracts of Hati Tanah and Sangkareho concentrate at concentration of $1 \%, 5 \%, 10 \%$, and $15 \%$ was done by Kirby-Bauer and the method diffusion used disc paper.

\section{Data analysis}

Performed by measuring the inhibitory zone diameter ethanol extracts, N-Butanol fraction of tuber Hati Tanah and Sangkareho leaves on the growth of Staphylococcus bacteria using sliding term. The results are presented in table and photo form along with a comparison between the results obtained with the standards set by the Clinical Laboratory Standart Institute (CLSI) (Tables 1-4).

\section{RESULTS}

Examination of ethanol extracts, N-Butanol fraction of Hati Tanah tuber and ethanol extracts Sangkareho leaves were done with 4 concentrations $(1 \%, 5 \%, 10 \%$, and $15 \%)$. The choice of concentration begins with the smallest concentration to get the Minimum Inhibitor Concentration (MIC) value of observation with focus on the potent low concentration to inhibit the growth of microorganisms.

The results of this study indicate the inhibition of ethanol extracts, N-Butanol fraction of Hati Tanah tubers and Sangkareho leaves on Staphylococcus aureus bacteria grown in MHA after incubation at $37^{\circ} \mathrm{C}$ for 24 hours. The ability of the drag is characterized by the formation of clear zones around the disc. In addition, when compared with the positive control used was Tetracycline and Clindamycin, the two simplicia have the ability drill which almost equal to Tetracycline especially ethanol extract of Hati Tanah tubers. In addition for the $\mathrm{N}$-Butanol fraction, it gave the same ability to inhibit the growth of

Table 1: Classification of positive control limit.

\begin{tabular}{cccc}
\hline \multirow{2}{*}{ Antimicrobial agent } & \multicolumn{3}{c}{ Test cultures (Zona diameter in mm) } \\
\cline { 2 - 4 } & Resistant & Intermediate & Susceptible \\
\hline Tetrasiklin & $\leq 14 \mathrm{~mm}$ & $15-18 \mathrm{~mm}$ & $\geq 19 \mathrm{~mm}$ \\
Staphylococcus aureus & & & \\
Clindamisin & $\leq 14 \mathrm{~mm}$ & $15-20 \mathrm{~mm}$ & $\geq 21 \mathrm{~mm}$ \\
Staphylococcus aureus & & & \\
\hline
\end{tabular}

Source: CLSI (2013)

Table 2: Obtacles zone implantation measurements of ethanol extracts hati tanah tubers on Staphylococcus aureus growth compared with CLSI.

\begin{tabular}{ccccccc}
\hline Test & Concentration (\%) & \multicolumn{3}{c}{ Experiment $(\mathrm{mm})$} & Average $(\mathrm{mm})$ & Interpretation of barrier \\
\cline { 3 - 5 } & & I & II & III & & Resistant \\
Positive & $1 \%$ & 12.8 & 12.9 & 13.1 & 12.93 & Intermediate \\
Control & $5 \%$ & 15.9 & 16.1 & 16.2 & 16.07 & Intermediate \\
Tetracycli & $10 \%$ & 16.5 & 16.8 & 17.2 & 16.83 & Susceptible \\
ne & $15 \%$ & 21.8 & 22.1 & 22.3 & 22.07 & Intermediate \\
Ethanol & $1 \%$ & 15.5 & 15.8 & 15.6 & 15.63 & Intermediate \\
Extracts of & $5 \%$ & 16.8 & 17.2 & 16.9 & 16.97 & Susceptible \\
Tuber Hati & $10 \%$ & 25.5 & 25.2 & 25.6 & 25.43 & Susceptible \\
Tanah & $15 \%$ & 28.4 & 28.2 & 28.6 & 28.40 & \\
\hline
\end{tabular}

Source: Primary Data, 2017

Information: Interpretation of Barriers (CLSI. 2013)

$\leq 14 \mathrm{~mm}$ : Resistant

$15-18 \mathrm{~mm}=$ Intermediate

$\geq 19 \mathrm{~mm}=$ Susceptible 
Table 3: Obtacles zone implantation measurements of $\mathrm{N}$-butanol frcations hati tanah tubers on Staphylococcus aureus growth compared with CLSI.

\begin{tabular}{|c|c|c|c|c|c|}
\hline \multirow[t]{2}{*}{ Uji } & \multirow[t]{2}{*}{ Konsentrasi } & \multicolumn{2}{|c|}{ Percobaan (mm) } & \multirow[t]{2}{*}{ Rata-rata } & \multirow[t]{2}{*}{ Interprestasi daya hambat } \\
\hline & & 1 & II & & \\
\hline & $1 \%$ & 33.3 & 35.6 & 34.45 & Susceptible \\
\hline Kontrol positif & $5 \%$ & 38.2 & 40.7 & 39.35 & Susceptible \\
\hline \multirow[t]{2}{*}{ Clindamisin } & $10 \%$ & 41.1 & 42.4 & 41.75 & Susceptible \\
\hline & $15 \%$ & 42.3 & 41.7 & 41.85 & Susceptible \\
\hline Ethanol & $1 \%$ & - & - & - & Resistant \\
\hline Extracts of & $5 \%$ & 20.3 & 21.5 & 20.90 & Intermediate \\
\hline tuber Hati & $10 \%$ & 22.1 & 24.6 & 23.35 & Susceptible \\
\hline \multirow[t]{2}{*}{ Tanah } & $15 \%$ & 25.7 & 26.7 & 26.20 & Susceptible \\
\hline & $1 \%$ & 12.2 & 19.3 & 15.65 & Intermediate \\
\hline N-butanol & $5 \%$ & 23.1 & 23.3 & 23.20 & Susceptible \\
\hline \multirow[t]{2}{*}{ Fraction } & $10 \%$ & 24.7 & 23.6 & 24.15 & Susceptible \\
\hline & $15 \%$ & 24.7 & 23.6 & 24.15 & Susceptible \\
\hline
\end{tabular}

Source: Primary Data, 2018

Information: Interpretation of Barriers (CLSI, 2013)

$\leq 14 \mathrm{~mm}=$ Resistant

15-20 $\mathrm{mm}=$ Intermediate

$\geq 21 \mathrm{~mm}=$ Susceptible

Table 4: Obtacles zone measurement result of sangkareho leaf ethanol extract on Staphylococcus aureus growth compared with CLSI.

\begin{tabular}{|c|c|c|c|c|c|c|}
\hline \multirow[t]{2}{*}{ Test sample } & \multirow[t]{2}{*}{ Concentration (\%) } & \multicolumn{3}{|c|}{ Experiment (mm) } & \multirow[t]{2}{*}{ Average (mm) } & \multirow[t]{2}{*}{ Interpretation of barrier } \\
\hline & & I & II & III & & \\
\hline \multirow[t]{4}{*}{ Tetracycline } & $1 \%$ & 12.25 & 12.9 & 13.3 & 12.81 & Resistant \\
\hline & $5 \%$ & 15.95 & 16 & 19.2 & 17.05 & Intermediate \\
\hline & $10 \%$ & 17.1 & 17.6 & 20.9 & 18.53 & Intermediate \\
\hline & $15 \%$ & 20.1 & 20.2 & 22.1 & 20.8 & Susceptible \\
\hline Sangkareho & $1 \%$ & 0.3 & 1.15 & 1.55 & 1 & Resistant \\
\hline \multirow[t]{3}{*}{ leaf extract } & $5 \%$ & 1.25 & 2.2 & 4.6 & 2.68 & Resistant \\
\hline & $10 \%$ & 2.2 & 3.1 & 6.4 & 3.9 & Resistant \\
\hline & $15 \%$ & 3.7 & 5.4 & 9.5 & 6.2 & Resistant \\
\hline
\end{tabular}

$\leq 14 \mathrm{~mm}=$ Resistant

15-18 $\mathrm{mm}=$ Intermediate

$\geq 19 \mathrm{~mm}=$ Susceptible

Staphylococcus aureus bacteria. When viewed the results of inhibitory test results, extracts ethanol of Hati Tanah tubers have greater inhibitory power compared to Sangkareho leaves. This can be affected by the secondary metabolite content present in the Hati Tanah more have activity as antibiotics.

\section{DISCUSSION}

The resistance response is caused by the active compound or secondary metabolite compounds in both of the simplicia. Both simplicia are based on the identification of the chemical compounds that have been done, the tuber of Hati Tanah and the leaves of Sangkareho positive contain flavonoid. Flavonoid is one of the secondary metabolites stay many contained in plants and one of its biological activity is as Antibiotic. Flavonoids work by inhibiting division or proliferation of bacterial cells. ${ }^{6}$ This compound binds proteins to microtubules in the cells and interferes with mitotic function resulting in inhibition of bacterial growth. The phenol compound as antibacterial is denaturing the protein bonds in the cell membrane so that the cell membrane lysates and allows the phenol to penetrate into the cytoplasm which causes the bacteria not to develop. In addition to flavonoids, the two simplliums also contain other secondary metabolites that have biological activity as antibiotics. Sangkareho leaf besides flavonoids contain alkaloid compounds that can inhibit bacterial growth. Alkaloids have an antibacterial ability with alkaloid work mechanism by interfering with peptidoglycan components in bacterial cells so that the cell wall layer is not formed completely and causes cell death. ${ }^{7}$ In addition, alkaloids work by disrupting the peptidoglycan component and inhibiting the topoisomerase enzyme has a very important role in the process of replication, transcription, and recombination of DNA by cutting and connecting a single strand or double strand of DNA. ${ }^{8}$ While the tuber of Hati Tanah In addition to containing antibiotic flavonoids, the tuber Hati Tanah also contains two secondary metabolites that have activity biological as antibiotics namely saponins and tannins. The mechanism of action of saponins as antibacterials is to reduce surface tension, resulting in increased permeability or leakage of cells and result in the intracellular compound will be released. This compound diffuses through the outer membrane and vulnerable cell wall, then binds the cytoplasmic membrane and interferes with and reduces the stability. This causes the cytoplasm to leak out of the cell resulting in cell death. ${ }^{9}$ Antimicrobial agents that interfere with cytoplasmic membranes are bactericidal. Saponin compounds can perform the mechanism of bacterial inhibition by forming complex compounds with bacterial cell membranes through hydrogen bonds, which can destroy the permeability properties of bacterial cell walls and eventually can cause cell death in bacteria.

Tannin is a polyphenol compound. ${ }^{10}$ The mechanism of action of tannin as an antibacterial is inhibiting the reversere transcriptase enzyme and 
DNA topoisomerase so that bacterial cells can not form. ${ }^{11}$ Tannin has antibacterial activity associated with its ability to activate microbial cell adhesion and also activates enzymes and interferes with protein transport in the inner lining of the cells. ${ }^{12}$ Tannins also have targets in the cell wall polypeptides resulting in less than perfect cell wall formation. This causes the bacterial cell to become lysed by both osmotic and physical pressure so that the bacterial cell will die. ${ }^{13}$ The complexity of iron ions with tannins can explain the toxicity of tannins. Microorganisms that grow under aerobic conditions require iron for many functions, including reduction of DNA ribonucleotide precursors. This is due to the strong iron binding capacity by tannin. ${ }^{14}$

When viewed from the content of active compounds or secondary metabolites contained of the Hati Tanah tubers and Sangkareho leaves, as well as the results of inhibitory test results can be concluded that the two simplisia have potential as a traditional medicine with pharmacological effects as antibiotics in Staphylococcus aureus bacteria. The results of this study can be used as a reference for further research such as research in the field of pharmaceutical technology. In addition, this study can be continued with a greater concentration of variations so that it can be known the largest concentration to inhibit the growth of Staphylococcus aureus bacteria.

\section{CONCLUSION}

Medicinal Herbs from Central Kalimantan, namely the Hati Tanah tuber and Sangkareho leaves have the potential to be developed into a traditional medicine that is efficacious in inhibiting the growth of Staphylococcus aureus bacteria.

\section{ACKNOWLEDGMENTS}

This research was partially supported by Overseas Seminar Assistance Program Directorate General of Research and Development Reinforcement, Ministry of Research, Technology and Higher Education (Kemenristekdikti), and I would like to take this opportunity to thank for the permanent support of Dr. Bulkani, M.Pd, rector of Universitas Muhammadiyah Palangkaraya, Central Kalimantan, Indonesia.

\section{CONFLICT OF INTEREST}

None.

\section{REFRENCES}

1. Wijayakusuma MH. Healing with Temulawak. Jakarta: Prima Pustaka Facilities 2007.

2. Krismawati A, Sabran M. Management of genetic resources of medicinal plants specific to central kalimantan. Palangkaraya: Central Kalimantan Agricultural Technology Assessment Institute; 2006.

3. Handayani R, Novaryatiin S, Widya AV. Identification of pharmacognostic of liver plants from palangka raya city of central kalimantan. J Surya Medika. 2015;1(1):53-61.

4. Jawetz, Ernest. Medical microbiology edition 20. Jakarta: EGC; 1996.

5. Clinical Laboratory Standard Institute. Performance standard for antimicrobial susceptibility testing, twentieth information supplement. USA; 2013.

6. Haerazi A, Dwi SDJ, Yayuk A. Test of antibacterial activity of kencur extract (Kaempferia galangal L.) on the growth of Staphylococcus aureus and Streptococcus viridans bacteria. Scientific Journal of Bioscientist Biological Education. 2016;2(1):75-82

7. Darsana IGO. Potential leaf binahong (Andredera cordifolia tenore) steenis in inhibiting the growth of escherichia coli bacteria in vitro. Journal of Indonesia Medicus Veterinus. 2012;1(3):337-51.

8. Campbell NA, Reece JB, Mitchell IG. Biology 5th edition. Jakarta: Erland; 2005

9. Cavalieri SJ, Rankin ID, Harbeck RJ, Sautter RS, McCarter YS, Sharp SE, et al. Manual of antimicrobial susceptibillity testing. USA: American Society for Microbiology; 2005.

10. Harborne JB. Phytochemical methods guide modern ways of analyzing plants Translator: Kosasih Padmawinata and Iwang Soediro. Second Issue. Bandung: ITB Publisher; 1987.

11. Nuria MC, Faizatun A, Smumantri. Antibacterial test of ethanol extract of jatropha leaf (Jatropha cuircas L) against Staphylococcus aureus ATCC 25923 , Escherichia coli ATCC 25922, and Salmonella typhi ATCC 1408. Journal of Agricultural Sciences. 2009;5:26-37.

12. Cowan MM. Plant products as antimicrobial agents. Clinical Microbiology Reviews. 1999;12:564-82.

13. Sari FP, Sari SM. Extraction of antimicrobial active ingredients from iodine plant (Jatropha multifida Linn) as alternative natural antibiotic raw material Semarang: Faculty of Engineering Diponegoro University; 2012.

14. Akiyama H, Fujii K, Yamasaki O, Oono T, Iwatsuki K. Antibacterial action of several tannin against Staphylococcus aureus. Journal of Antimicrobial Chemotherapy. 2001;48:487-91. 


\section{GRAPHICAL ABSTRACT}

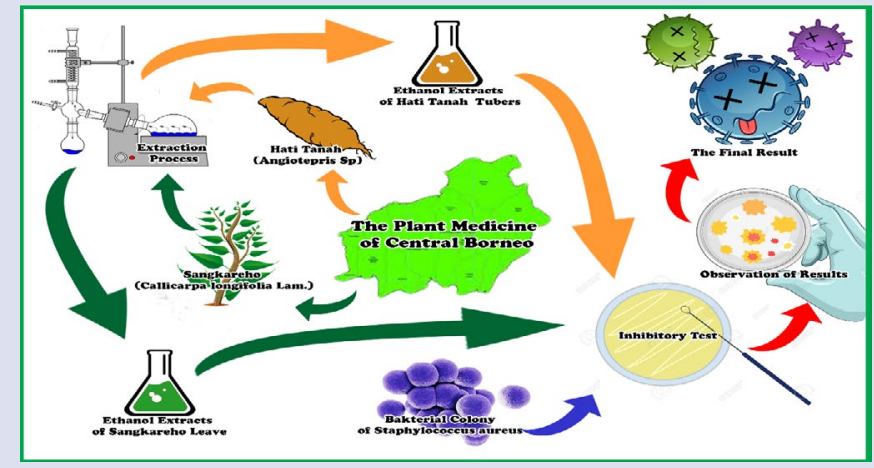

\section{SUMMARY}

- Hati Tanah (Angiotepris Sp) and Sangkareho (Callicarpa longifolia Lam.) are the plant medicine of central borneo

- Both medicinal plants has been utilized by the community as a traditional medicine to treat minor moderate injuries such as postpartum

- HatiTanah tubers and Sangkareho leaves has potential as a traditional medicine in inhibiting and killing Staphylococcus aureus bacteria

\section{ABOUT AUTHORS}

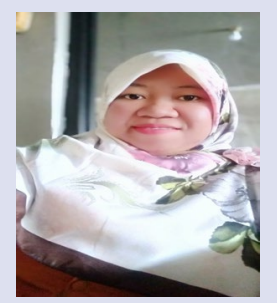

Rezqi Handayani is a lecturer at Pharmaceutical Study Program, Faculty of Health Science, Universitas Muhammadiyah Palangkaraya, Central Borneo Indonesia. She has a lot of research in the field of developing medicinal plants from central Kalimantan. And know she is the chair of the study center for traditional tropical medicine in Central Borneo.

Cite this article: Handayani R. The Potential Herbs of Medicinal Forests from Central Kalimantan as a Inhibitor of Staphylococcus aureus. Pharmacog J. 2019;11(4):740-4. 